\title{
Replacing maize silage plus soybean meal with red clover silage plus wheat in diets for lactating dairy cows
}

\author{
Franziska Schulz, ${ }^{*}$ Edwin Westreicher-Kristen, ${ }^{* 1}$ Karin Knappstein, $\dagger$ Joachim Molkentin, $\dagger$ \\ and Andreas Susenbeth* \\ *Institute of Animal Nutrition and Physiology, Christian-Albrechts-Universität zu Kiel, 24118 Kiel, Germany \\ †Department of Safety and Quality of Milk and Fish Products, Max Rubner-Institute, 24103 Kiel, Germany
}

\begin{abstract}
The objectives of this study were to evaluate the effects of replacing maize silage plus soybean meal with red clover silage (RCS) plus wheat on feed intake, diet digestibility, $\mathrm{N}$ partitioning, urinary excretion of purine derivatives, and milk production in dairy cows. Fortyfour lactating German Holstein cows were used in a 4 $\times 4$ Latin square design with 21-d periods composed of a 13-d adaptation phase followed by an 8-d sampling phase. Experimental diets offered as total mixed ration consisted of a constant forage-to-concentrate ratio (75:25) with targeted proportions of RCS-to-maize silage of 15:60 $\left(\mathrm{RCS}_{15}\right), 30: 45\left(\mathrm{RCS}_{30}\right), 45: 30\left(\mathrm{RCS}_{45}\right)$, and 60:15 $\left(\mathrm{RCS}_{60}\right)$ on a dry matter $(\mathrm{DM})$ basis. Increasing the proportion of RCS plus wheat in the diet decreased linearly the intake of DM from 22.4 to 19.8 $\mathrm{kg} / \mathrm{d}$, and of organic matter from 21.1 to $18.1 \mathrm{~kg} / \mathrm{d}$. The apparent total tract digestibility (ATTD) of DM and organic matter did not differ across diets and averaged 68.4 and $70.5 \%$, respectively. However, ATTD of $\mathrm{N}$ decreased linearly from 68.5 to $63.2 \%$, whereas ATTD of neutral detergent fiber and acid detergent fiber increased linearly from 50.4 to $59.6 \%$ and from 48.4 to $57.7 \%$, respectively, when increasing the proportion of RCS plus wheat. Fecal N excretion increased from $31.6\left(\mathrm{RCS}_{15}\right)$ to $37.2 \%\left(\mathrm{RCS}_{60}\right)$ of $\mathrm{N}$ intake, whereas urinary $\mathrm{N}$ excretion was the lowest (32.8\% of $\mathrm{N}$ intake) with $\mathrm{RCS}_{45}$. Hence, $\mathrm{N}$ efficiency (milk $\mathrm{N} / \mathrm{N}$ intake) decreased linearly with incremental levels of RCS plus wheat, being the lowest when feeding $\mathrm{RCS}_{60}(25.4 \%)$, probably due to increased nonprotein $\mathrm{N}$ proportion in total dietary N. Urinary excretion of purine derivatives decreased linearly from 378 to $339 \mathrm{mmol} / \mathrm{d}$, which suggests that increasing levels of RCS plus wheat reduced the microbial crude protein flow at the duodenum. Milk yield and milk protein concentration declined linearly
\end{abstract}

Received July 31, 2017.

Accepted October 10, 2017.

${ }^{1}$ Corresponding author: westreicher@aninut.uni-kiel.de from 35.9 to $30.2 \mathrm{~kg} / \mathrm{d}$ and from 3.20 to $3.01 \%$, respectively, when increasing the proportion of RCS plus wheat. In conclusion, caution should be taken before introducing high levels of RCS plus wheat in diets of high-yielding dairy cows. However, RCS plus wheat can be included up to $30 \%$ of the dairy cow diet (DM basis) without a reduction in lactation performance.

Key words: digestibility, nitrogen partitioning, purine derivative, milk composition

\section{INTRODUCTION}

In recent years, the interest in using forage legumes as a source of home-grown protein in dairy farming systems has increased. Red clover (Trifolium pratense L.) is one of the most important forage legumes for producing high-CP silage in northern Europe and North America (Moorby et al., 2016). Ensiling forage legumes is associated with an extensive protein breakdown of true protein to NPN compounds, which may result in poor $\mathrm{N}$ efficiency (milk $\mathrm{N} / \mathrm{N}$ intake) in dairy cows (Broderick, 1995; Sullivan and Hatfield, 2006). Red clover has shown lower CP degradation and NPN formation during ensiling than alfalfa (Jones et al., 1995; Sullivan and Hatfield, 2006; Hymes-Fecht et al., 2013) and birdsfoot trefoil (Hymes-Fecht et al., 2013). This lower CP degradation in red clover is attributed to the action of the enzyme polyphenol oxidase (PPO; Jones et al., 1995; Sullivan and Hatfield, 2006), which catalyzes the oxidation of endogenous $o$-diphenols to $o$-quinones that quickly react with nucleophilic sites, such as AA within proteins, leading to the formation of protein-bound phenols (Bittner, 2006; Lee, 2014). Reduced ruminal CP degradation was associated with a greater postruminal flow of dietary NAN when feeding red clover silage (RCS) than grass silage in dairy cows (Vanhatalo et al., 2009; Halmemies-Beauchet-Filleau et al., 2014) and steers (Merry et al., 2006). The latter suggests that the postharvest formation of proteinbound phenol complexes also provides protection of plant protein from breakdown in the rumen. Hence, 
feeding RCS to dairy cows may enhance the supply of RUP at the duodenum, thus having the potential to improve $\mathrm{N}$ efficiency. Nevertheless, some studies have found a decline in N efficiency when feeding RCS compared with grass silage (Dewhurst et al., 2003b; Moorby et al., 2009; Halmemies-Beauchet-Filleau et al., 2014), possibly due to its higher CP concentration and lower energy content.

Due to its high starch concentration, maize silage (MS) is a significant source of rapidly fermentable carbohydrates and is a good complement for the high $\mathrm{CP}$ concentration and low energy content of RCS. The combination of RCS with MS might therefore represent an important means of stimulating microbial CP (MCP) synthesis and improving N-use efficiency in the rumen. In line with this, some studies demonstrated improvements in feed intake and milk production when feeding RCS-MS mixtures (Moorby et al., 2016) or RCS-MS mixtures compared with RCS (Broderick et al., 2001; Hoffman and Bauman, 2003). Results from published studies comparing RCS-MS or RCS-grass silage mixtures have frequently been confounded due to increased concentration of dietary $\mathrm{CP}$ with increasing RCS ratio. Moreover, due to the high CP concentration and the high proportion of RUP in CP, the use of RCS in diets of dairy cows may reduce the use of feed protein supplements, such as rapeseed meal or soybean meal (SBM).

The aim of the present study was to evaluate the effects of replacing MS plus SBM with RCS plus wheat on feed intake, diet digestibility, $\mathrm{N}$ partitioning, and urinary purine derivatives (PD) excretion as an indicator for MCP flow to the duodenum, as well as on milk yield and composition, in dairy cows. We hypothesized that RCS could partially replace SBM in the diet without a reduction in lactation performance.

\section{MATERIALS AND METHODS}

\section{Animals, Diets, and Experimental Design}

The study reported herein was performed in accordance with the German Animal Welfare Act (Federal Republic of Germany, 2014) and approved by the Animal Welfare Commission of the Ministry of Energy, Agriculture, the Environment and Rural Areas of the federal state of Schleswig-Holstein (V 242-72241.123-5). The feeding experiment was carried out with 44 German Holstein cows at the experimental farm Schädtbek of the Max Rubner-Institute (Dobersdorf, Germany). Cows were randomly assigned to 4 groups according to milk yield, DIM, lactation number, and BW, averaging $($ mean $\pm \mathrm{SD}) 38.7 \pm 7.3 \mathrm{~kg} / \mathrm{d}, 149 \pm 103 \mathrm{~d}, 1.9 \pm$
1.1 , and $624 \pm 52 \mathrm{~kg}$ at the start of the experiment, respectively.

Red clover (Trifolium pratense L. 'Harmonie') and maize (Zea mays 'Amagrano,' LG 30.222, and 'Saludo') were grown as pure stands. The RCS was prepared from the second cut after $43 \mathrm{~d}$ of regrowth (first production year) at the early flowering stage. Red clover was harvested with a mower-conditioner kept at a cutting height of $5 \mathrm{~cm}$ and field-wilted for approximately $48 \mathrm{~h}$ until the forage was approximately 35\% DM. Mowed forage was chopped to a length of approximately $15 \mathrm{~cm}$ and ensiled in bales using an inoculant (BIO-SIL, Dr. Pieper Technologie und Produktentwicklung GmbH, Wuthenow, Germany) containing Lactobacillus plantarum strains DSM 8862 and DSM 8866 (reconstituted in unchlorinated water and applied at a dosage of $3 \times$ $10^{3} \mathrm{cfu} / \mathrm{g}$ forage). Whole-crop maize at the dough stage of maturity was harvested at a stubble height of $40 \mathrm{~cm}$ and chopped with a forage harvester equipped with a kernel processor to a theoretical length of 0.6 to $1 \mathrm{~cm}$. Maize was ensiled in a bunker silo without additives. The 4 experimental diets offered as TMR consisted of a constant forage-to-concentrate ratio $75: 25$ on a DM basis) with targeted proportions of RCS to MS in diet DM of 15:60 $\left(\mathbf{R C S}_{15}\right), 30: 45\left(\mathbf{R C S}_{\mathbf{3 0}}\right), 45: 30\left(\mathbf{R C S}_{\mathbf{4 5}}\right)$, and 60:15 $\left(\mathbf{R C S}_{60}\right)$. All diets contained (on DM basis) approximately 9\% ground lupin seeds and approximately $16 \%$ SBM plus ground wheat in different ratios to obtain isonitrogenous diets. The chemical composition of the individual feed ingredients is presented in Table 1, whereas Table 2 provides the ingredients and the chemical composition of the 4 experimental diets. Every morning before feeding, individual components of the diets were added to a mixer wagon (Triomix 1-800, Trioliet BV, Oldenzaal, the Netherlands) and thoroughly mixed. Each experimental diet was individually prepared and was offered to the cows once daily at approximately $0600 \mathrm{~h}$ for ad libitum consumption. Cows were kept in a freestall barn equipped with cubicles bedded with chopped straw and had free access to water. Cows were housed and fed as groups (4 groups of 11 cows each). Animal-to-feeding place ratio and animal-to-cubicle ratio were both 1:1.

The experimental design was a $4 \times 4$ Latin square, with each experimental period lasting $21 \mathrm{~d}$. Each period consisted of $13 \mathrm{~d}$ for diet adaption followed by $8 \mathrm{~d}$ for data and sample collection. For the estimation of fecal excretion, $30 \mathrm{~g}$ of the external marker titanium dioxide $\left(\mathrm{TiO}_{2}\right.$; Kronos 1171, Kronos Titan GmbH, Leverkusen, Germany) was weighed into hard gelatin capsules (pig gelatin, size $30 \times 90 \mathrm{~mm}$, approximately $59 \mathrm{~mL}$, Type 36, Capsula GmbH, Ratingen, Germany) and administered orally to each cow using a bolus applicator once 
Table 1. Chemical composition of feed ingredients

\begin{tabular}{|c|c|c|c|c|c|}
\hline $\begin{array}{l}\text { Item, } \% \text { of DM } \\
\text { (unless otherwise stated) }\end{array}$ & Red clover silage & Maize silage & Lupin seeds & Soybean meal & Wheat grain \\
\hline $\mathrm{OM}$ & 88.2 & 96.6 & 96.0 & 92.8 & 98.3 \\
\hline $\mathrm{CP}$ & 19.4 & 7.12 & 35.1 & 45.7 & 11.5 \\
\hline Starch & $\mathrm{ND}^{1}$ & 36.0 & 0.72 & 1.90 & 66.2 \\
\hline NDF & 38.3 & 38.4 & 25.9 & 18.8 & 14.8 \\
\hline $\mathrm{ADF}$ & 30.6 & 22.7 & 18.1 & 11.5 & 3.30 \\
\hline NDIN, $\%$ of total $\mathrm{N}$ & 17.6 & 8.95 & 1.75 & 3.41 & 12.0 \\
\hline ADIN, $\%$ of total $\mathrm{N}$ & 4.20 & 4.70 & 1.25 & 2.40 & 1.68 \\
\hline $\mathrm{ME},{ }^{2} \mathrm{MJ} / \mathrm{kg} \mathrm{DM}$ & 9.54 & 11.4 & 13.9 & 12.7 & 13.2 \\
\hline
\end{tabular}

${ }^{1} \mathrm{ND}=$ not determined.

${ }^{2}$ Determined based on corrected in vitro gas production after $24 \mathrm{~h}(\mathrm{~mL} / 200 \mathrm{mg}$ of DM) using the Hohenheim gas test (method 25.1; VDLUFA, 2007) and chemical composition according to Menke and Steingass (1988). Published in Westreicher-Kristen et al. (2017).

daily at approximately $0700 \mathrm{~h}$. The $\mathrm{TiO}_{2}$ administration was initiated $5 \mathrm{~d}$ before the first sampling of feces to reach the equilibrium of $\mathrm{TiO}_{2}$ intake and excretion

Table 2. Ingredients and chemical composition of the experimental diets

\begin{tabular}{lcccc}
\hline & \multicolumn{4}{c}{ Diet $^{1}$} \\
\cline { 2 - 5 } Item & $\mathrm{RCS}_{15}$ & $\mathrm{RCS}_{30}$ & $\mathrm{RCS}_{45}$ & RCS $_{60}$ \\
\hline Ingredient, \% of DM & 13.6 & 27.5 & 42.1 & 57.1 \\
Red clover silage & 61.0 & 46.6 & 31.6 & 16.2 \\
Maize silage & 8.59 & 8.70 & 8.88 & 8.96 \\
Lupin seeds & 15.9 & 10.8 & 5.50 & - \\
Soybean meal & - & 5.49 & 11.0 & 16.8 \\
Wheat grain & 0.91 & 0.91 & 0.92 & 0.94 \\
Premix & & & & \\
Chemical composition & 94.0 & 92.9 & 91.6 & 90.7 \\
OM, \% of DM & 17.2 & 17.4 & 17.3 & 17.5 \\
CP, \% of DM & 2.14 & 2.13 & 2.05 & 2.02 \\
Ether extract, \% of DM & 23.2 & 20.5 & 18.0 & 17.0 \\
Starch, \% of DM & 5.62 & 2.93 & 2.51 & 2.84 \\
Sugar, \% of DM & 34.7 & 34.0 & 35.2 & 35.3 \\
NDF, \% of DM & 21.9 & 22.5 & 24.5 & 25.2 \\
ADF, \% of DM & 2.80 & 3.24 & 3.69 & 4.10 \\
ADL, \% of DM & 26.2 & 30.5 & 35.2 & 37.4 \\
NPN, \% of total N & 6.96 & 9.08 & 11.8 & 14.0 \\
NDIN, \% of total N & 2.45 & 3.01 & 3.75 & 3.81 \\
ADIN, \% of total N & 11.6 & 11.4 & 10.9 & 10.7 \\
ME, ${ }^{3}$ MJ /kg DM &
\end{tabular}

${ }^{1}$ Experimetal diets were composed of forage and concentrates (75:25), with targeted levels of red clover silage (RCS) in TMR of $15 \%\left(\mathrm{RCS}_{15}\right)$, $30 \%\left(\mathrm{RCS}_{30}\right), 45 \%\left(\mathrm{RCS}_{45}\right)$, and $60 \%\left(\mathrm{RCS}_{60}\right)$ on a DM basis.

${ }^{2}$ Composed of $0.3 \%$ of salt and the rest of a mineral-vitamin premix. Composition of the mineral-vitamin premix (in $\mathrm{kg}$ of fresh matter and according to manufacturer specifications): $200 \mathrm{~g}$ of $\mathrm{Ca}, 80 \mathrm{~g}$ of Na, $40 \mathrm{~g}$ of $\mathrm{Mg}, 40 \mathrm{~g}$ of P, 8,000 $\mathrm{mg}$ of $\mathrm{Zn}, 6,400 \mathrm{mg}$ of $\mathrm{Mn}, 1,200 \mathrm{mg}$ of $\mathrm{Cu}, 160$ $\mathrm{mg}$ of I, $70 \mathrm{mg}$ of Co, $45 \mathrm{mg}$ of Se, 5,000 mg of vitamin E, 1,250,000 IU of vitamin A, and 125,000 IU of vitamin D.

${ }^{3}$ Determined based on corrected in vitro gas production after $24 \mathrm{~h}$ (mL/200 mg of DM) using the Hohenheim gas test (method 25.1; VDLUFA, 2007) and chemical composition according to Menke and Steingass (1988). Published in Westreicher-Kristen et al. (2017). after the start of oral administration (Glindemann et al., 2009).

\section{Sampling and Chemical Analyses}

Feed. During the sampling phase within each period, the daily amount of diet offered and refused was recorded on a group basis. Daily samples of approximately $2 \mathrm{~kg}$ of fresh matter (FM) of RCS, MS, each diet, and refusals from each diet were collected and stored at $-20^{\circ} \mathrm{C}$. Daily samples were pooled per period by mixing equal amounts (on FM basis). For chemical analysis of RCS and MS, the pooled samples were further pooled across periods. Samples of refusals were blended by period proportional to the daily refusal weights (on FM basis). Silages, diets, and refusals were freeze-dried for $72 \mathrm{~h}$ (VirTis Freezemobile 12 EL, VirTis, Warminster Township, PA). Samples of lupin seeds, SBM, and wheat were collected twice during each sample phase, stored at $4^{\circ} \mathrm{C}$, and pooled on an equal-weight basis (on FM basis) across periods. Dried samples of diets, refusals, and individual feed ingredients were ground to pass a 1-mm screen (Retsch centrifugal mill ZM1, Retsch GmbH, Haan, Germany). Additionally, a subset of samples was ground through 2- and 0.2-mm screens for analysis of fiber fractions and starch, respectively. Feed samples were analyzed following the official analytical methods in Germany (VDLUFA, 2007) for DM, crude ash (CA), CP, and ether extract (methods 3.1, 8.1, 4.1.1, and 5.1.1, respectively). Concentrations of NDF (method 6.5.1) and ADF (method 6.5.2), both inclusive of residual ash, as well as ADL (method 6.5.3) were determined with the ANKOM Filter Bag Method by using ANKOM $^{200}$ Fiber Analyzer (ANKOM Technology, Macedon, NY). Heat-stable $\alpha$-amylase was added during NDF extraction. Sugar content was determined only in TMR (method 7.1.1). Starch concentration was 
assayed after enzymatic hydrolysis and subsequent oxidation by glucose oxidase using quinonimine as a colorimetric indicator (Brandt et al., 1987). The concentration of ME of the diets and individual components of diets was determined based on corrected in vitro gas production after $24 \mathrm{~h}(\mathrm{~mL} / 200 \mathrm{mg}$ of $\mathrm{DM})$ using the Hohenheim gas test (method 25.1; VDLUFA, 2007) and nutrient composition according to Menke and Steingass (1988; equation 12f). Concentrations of NPN, NDIN, and ADIN were determined as described by Licitra et al. (1996).

Feces and Urine. Fecal grab samples $(\sim 600 \mathrm{~g}$ of FM) were collected from all cows once daily on d 15 , 17,19 , and 21 at $1930,1530,1130$, and $0730 \mathrm{~h}$, respectively, and stored at $-20^{\circ} \mathrm{C}$. The sampling pattern was applied to consider diurnal and day-to-day variations in marker excretion (Glindemann et al., 2009). Thawed fecal samples were pooled on an equal-weight basis (on FM basis) by cow and period and stored at $-20^{\circ} \mathrm{C}$ until analyzed. To reduce the effort and expense for NDF and ADF analysis in feces, feces were not analyzed per cow; instead, 2 subgroups of 5 and 6 animals within each period and experimental treatment were generated and their feces were pooled per subgroup, resulting in 8 observations per treatment. Fecal samples were freeze-dried for $96 \mathrm{~h}$ (VirTis Freezemobile $12 \mathrm{EL}$, VirTis, Warminster Township, PA) and ground to pass a 2-mm screen (Retsch centrifugal mill ZM1, Retsch $\mathrm{GmbH})$. Concentrations of NDF and ADF in feces were analyzed as described above, except that heat-stable $\alpha$-amylase was not added during NDF extraction. Fresh fecal samples were analyzed for DM and CA, using the above mentioned methods, as well as $\mathrm{N}$ by the Kjeldahl procedure (method 4.1.1; VDLUFA, 2007). Titanium dioxide concentration of fecal samples was determined as described by Glindemann et al. (2009).

Spot urine samples $(\sim 600 \mathrm{~mL})$ were obtained from all cows once daily on d 14, 16, 18, and 20 at 0730 , 1930,1530 , and $1130 \mathrm{~h}$, respectively, by manual stimulation of the region around the vulva. This sampling design was applied to account for possible diurnal and day-to-day variations in urinary excretion of $\mathrm{PD}$ and $\mathrm{N}$ (Castro-Montoya et al., 2016). Immediately after collection, urine was acidified to $\mathrm{pH}<3$ using $20 \%$ (vol/ vol) $\mathrm{H}_{2} \mathrm{SO}_{4}$ to avoid volatilization of $\mathrm{N}$ compounds, and stored at $-20^{\circ} \mathrm{C}$. After thawing at room temperature, urine samples were pooled on an equal-volume basis by cow and period and stored at $-20^{\circ} \mathrm{C}$ for $\mathrm{N}$ analysis. For PD analysis, urine samples were only analyzed for allantoin and uric acid concentrations as described by Castro-Montoya et al. (2016), because xanthine and hypoxanthine are reported to be almost absent in cattle urine (Verbic et al., 1990). For determination of urinary $\mathrm{PD}, 500 \mathrm{~mL}$ of the pooled urine was filtered (MN 612
1/4, $320 \mathrm{~mm} \varnothing$, Macherey-Nagel GmbH \& Co. KG, Düren, Germany). From this filtrate, 2 aliquots of $20 \mathrm{~mL}$ were diluted $(1: 5, \mathrm{vol} / \mathrm{vol})$ with double-distilled water, and 4 aliquots (2 aliquots each for determination of allantoin and uric acid) of $10 \mathrm{~mL}$ were taken and stored at $-20^{\circ} \mathrm{C}$. The diluted aliquots $(1: 5, \mathrm{vol} /$ vol) were further diluted with double distilled water to 1:25 for allantoin and 1:20 for uric acid analysis. The PD analysis was conducted using HPLC (JASCO HSS-1500, Groß-Umstadt, Germany), followed by peak area analysis with Galaxie Chromatography Software Version 1.10.0.5590 (Agilent Technologies, Santa Clara, CA).

Milk. Cows were milked twice daily starting at 0500 and $1430 \mathrm{~h}$. Milk yield was recorded at each milking by using calibrated electronic milk meters (Metatron P21, GEA Farm Technologies GmbH, Bönen, Germany). Samples of milk were collected from each cow once per day alternating morning and afternoon milking from d 14 to 21 of each period. Milk samples were conserved with preservative $(0.2 \mathrm{~g}$ of bronopol solution $/ 40 \mathrm{~mL}$ of milk), kept refrigerated at $4^{\circ} \mathrm{C}$, and afterward analyzed for fat, total protein, lactose, and urea at an official milk control laboratory (Landeskontrollverband SchleswigHolstein, Kiel, Germany), using Fourier transform infrared spectroscopy (MilkoScan FT+, FOSS Analytical, Hillerød, Denmark). To compute concentration of milk components, analysis results were weighted proportionally to the milk yield at individual milking of each cow.

\section{Calculations}

Fecal excretion of DM was estimated for each cow by dividing the orally administered dose of $\mathrm{TiO}_{2}$ by fecal $\mathrm{TiO}_{2}$ concentration, assuming a fecal recovery of $\mathrm{TiO}_{2}$ of $100 \%$ (Glindemann et al., 2009). Apparent total-tract digestibility (ATTD) of DM, OM, N, NDF, and ADF was computed on a group basis as ATTD (\%) $=[($ intake - feces excretion $) /$ intake $] \times 100$. For this, intake is in kilograms per day on a DM basis and was calculated on a group basis as the difference between the average of the daily offered and refused DM amount of diet; feces excretion is in kilograms per day on a DM basis and was averaged per group. Afterward, the intakes of DM and OM were calculated for each cow as [fecal excretion (DM or OM, kg/d)/(100 - ATTD (DM or OM, \%)] $\times 100$. Urinary $\mathrm{N}$ excretion was calculated as the difference between $\mathrm{N}$ intake and $\mathrm{N}$ excretion via feces and milk (total milk protein/6.38). Urine volume was estimated by dividing urinary $\mathrm{N}$ excretion by $\mathrm{N}$ concentration in urine. Concentration of SNF was calculated on the basis of concentrations of protein and lactose in milk. Yield of ECM (4.0\% fat, $3.4 \%$ protein) was computed according to GfE (2001) considering 
a specific additional amount of energy $(0.1 \mathrm{MJ} / \mathrm{kg}$ of milk) and scaling to an energy content of $3.28 \mathrm{MJ} / \mathrm{kg}$ of ECM as ECM $(\mathrm{kg})=$ milk yield $(\mathrm{kg}) \times[(0.38 \times$ milk fat $(\%)+0.21 \times$ milk protein $(\%)+1.05) / 3.28]$.

\section{Statistical Analyses}

Measurements of milk yield and composition of d 14 and 15 of the first period were not used due to inadequate sampling. All statistical analyses were conducted using the software $\mathrm{R}$ version 3.1.1 (The R Foundation for Statistical Computing, Vienna, Austria). Data were normally distributed and homoscedastic, proven by a graphical residual analysis. Arithmetic means per cow and period were calculated and used for statistical analyses, except for ATTD, for which a period mean was used. The following statistical mixed model was used for all variables (except for ATTD):

$$
Y_{i j k l}=\mu+P_{i}+G_{j}+C_{k(j)}+T_{l}+e_{i j k l},
$$

where $Y_{i j k l}$ is the dependent variable, $\mu$ is the overall mean, $P_{i}$ is the random effect of period $i(i=1-4), G_{j}$ is the random effect of group $j(j=1-4), C_{k(j)}$ is the random effect of cow $k$ (within group $j ; k=1-11$ ), $T_{l}$ is the fixed effect of dietary treatment $l(l=1-4)$, and $e_{i j k l}$ is the random residual error. Apparent total-tract diet digestibility was analyzed according to the model

$$
Y_{i j k}=\mu+P_{i}+G_{j}+T_{k}+e_{i j k},
$$

where $Y_{i j k}$ is the dependent variable, $\mu$ is the overall mean, $P_{i}$ is the random effect of period $i(i=1-4)$, $G_{j}$ is the random effect of group $j(j=1-4), T_{k}$ is the fixed effect of dietary treatment $l(l=1-4)$, and $e_{i j k}$ is the random residual error. Data were analyzed by ANOVA to identify treatment effects. Multiple contrast tests related to Tukey were conducted for treatment comparisons. In addition, orthogonal polynomial contrasts were used to test for linear and quadratic effects of RCS levels on response variables. All reported values are LSM and significance was declared at $P<0.05$.

\section{RESULTS}

\section{Chemical Composition of Diets}

Crude protein and NDF concentrations were equal across diets and averaged 17.4 and $34.8 \%$ of DM, respectively (Table 2). Increasing the proportion of RCS plus wheat in the diet resulted in a decline of starch from 23.2 to $17.0 \%$ and ME from 11.6 to $10.7 \mathrm{MJ} /$ $\mathrm{kg}$ of DM. Conversely, ADF and ADL concentrations increased moderately from 21.9 to $25.2 \%$ and from 2.8 to $4.1 \%$, respectively, when increasing RCS from 15 to $60 \%$ in the diets.

\section{Feed Intake, Fecal Excretion, and ATTD}

Treatment effects on feed intake, fecal excretion, and ATTD are shown in Table 3. Increasing the proportion of RCS plus wheat in the diet decreased linearly the intake of DM and OM $(P<0.001$ for both $)$ from 22.4 to $19.8 \mathrm{~kg} / \mathrm{d}$ and from 21.1 to $18.1 \mathrm{~kg} / \mathrm{d}$, respectively. The ATTD of DM and OM did not differ $(P=0.08$ and $P=0.25$, respectively) and averaged 68.4 and $70.5 \%$ across diets, respectively. Apparent total-tract $\mathrm{N}$ digestibility decreased linearly $(P<0.001)$ from 68.5 to $63.2 \%$, whereas ATTD of NDF and ADF increased linearly $(P=0.002$ for both) from 50.4 to $59.6 \%$ and from 48.4 to $57.7 \%$, respectively, when the proportion of RCS plus wheat was increased in the diet.

\section{Nitrogen Partitioning and Urinary Excretion of PD}

Due to the equal CP concentration across diets, differences in $\mathrm{N}$ intake between diets reflected differences in DMI (Table 4). Thus, $\mathrm{N}$ intake declined linearly $(P$ $<0.001$ ) from 628 to $561 \mathrm{~g} / \mathrm{d}$ when proportion of RCS plus wheat was increased in the diet. When expressed as percentages of $\mathrm{N}$ intake, increasing the proportion of RCS plus wheat had both linear and quadratic $(P<$ 0.001 ) effects on fecal and urinary $\mathrm{N}$ excretion. Fecal N excretion increased from 31.6 to $37.2 \%$ when increasing RCS plus wheat in the diet. Interestingly, fecal N excretion was the highest $(38.8 \%)$ and urinary $\mathrm{N}$ excretion was the lowest $(32.8 \%)$ with $\mathrm{RCS}_{45}$. Nitrogen efficiency (milk N/N intake) declined linearly $(P<0.001)$ from 29.0 to $25.4 \%$ with increasing the proportion of RCS plus wheat. Urinary excretion of PD decreased linearly $(P=0.004)$ from 378 to $339 \mathrm{mmol} / \mathrm{d}$ with increasing proportion of RCS plus wheat in the diet (Table 4); however, urinary PD excretion related to ATTD of OM did not differ $(P=0.06)$ and averaged $25.1 \mathrm{mmol} / \mathrm{kg}$ across diets.

\section{Milk Yield and Milk Composition}

Milk yield declined linearly $(P<0.001)$ from 35.9 to $30.2 \mathrm{~kg} / \mathrm{d}$ with increasing proportion of RCS plus wheat in the diet (Table 5). Milk fat concentration was higher $(P=0.03)$ when cows were fed $\mathrm{RCS}_{45}(4.04 \%)$ rather than $\mathrm{RCS}_{30}(3.94 \%)$. However, neither a linear $(P=0.84)$ nor a quadratic effect $(P=0.83)$ on milk fat concentration could be noted. Milk protein and SNF concentrations declined linearly $(P<0.001$ for both), from 3.20 to $3.01 \%$ and from 8.74 to $8.53 \%$, with increasing proportions of RCS plus wheat, respectively; 
Table 3. Feed intake, fecal excretion, and apparent total-tract digestibility ${ }^{1}$ (ATTD) in lactating dairy cows fed the 4 experimental diets

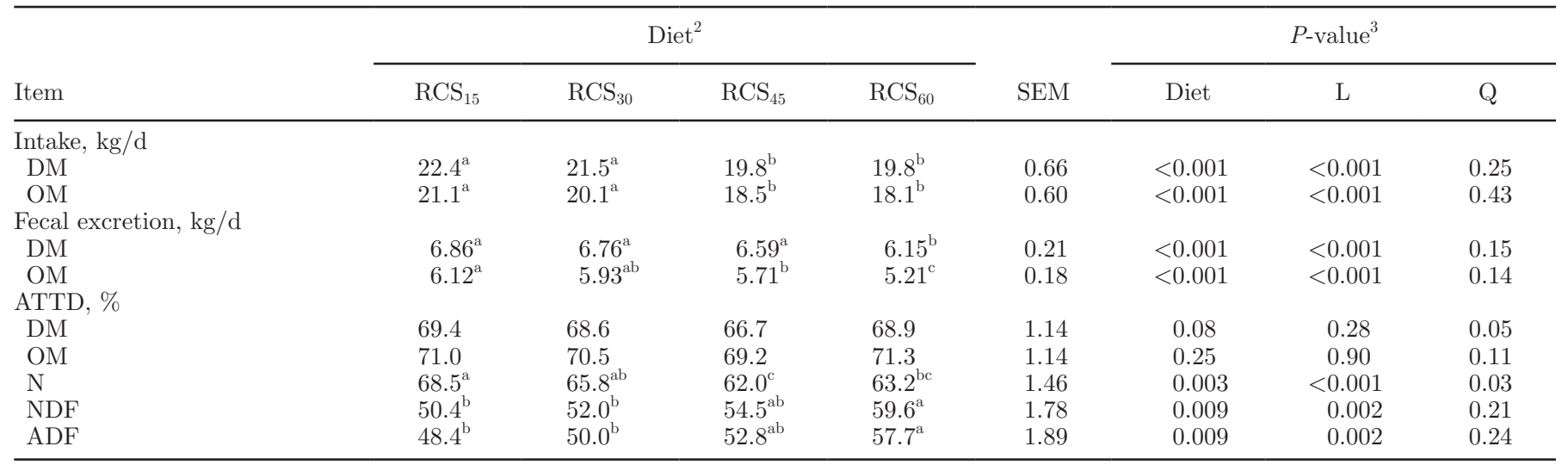

${ }^{\mathrm{a}-\mathrm{C}} \mathrm{LSM}$ within the same row with different superscripts differ $(P<0.05)$.

${ }^{1}$ Digestibility measured per group of cows $(n=4)$. For details see Materials and Methods.

${ }^{2}$ Experimental diets were composed of forage and concentrates (75:25), with targeted levels of red clover silage (RCS) in TMR of $15 \%$ (RCS 15 ), $30 \%\left(\mathrm{RCS}_{30}\right), 45 \%\left(\mathrm{RCS}_{45}\right)$, and $60 \%\left(\mathrm{RCS}_{60}\right)$ on a DM basis.

${ }^{3} \mathrm{~L}=$ linear effect; $\mathrm{Q}=$ quadratic effect.

milk lactose concentration was not affected $(P=0.65)$. Increasing the proportion of RCS plus wheat decreased linearly $(P<0.001)$ yield of ECM, fat, protein, lactose, and SNF, which was mainly due to the depressed milk yield. A quadratic effect $(P=0.006)$ was found for milk urea concentration, with the lowest value $(292 \mathrm{mg} / \mathrm{kg}$ milk) with $\mathrm{RCS}_{45}$.

\section{DISCUSSION}

\section{ATTD and Feed Intake}

The ATTD of DM and OM were not different among diets, whereas ATTD of NDF and ADF was increased with increasing proportion of RCS plus wheat. Moorby

Table 4. Nitrogen excretion, partitioning of dietary N, and urinary excretion of purine derivatives (PD) in lactating dairy cows fed the 4 experimental diets

\begin{tabular}{|c|c|c|c|c|c|c|c|c|}
\hline Item & \multicolumn{4}{|c|}{$\operatorname{Diet}^{1}$} & SEM & \multicolumn{3}{|c|}{$P$-value ${ }^{2}$} \\
\hline \multirow{2}{*}{\multicolumn{9}{|c|}{ N excretion, g/d }} \\
\hline & & & & & & & & \\
\hline Feces & $198^{\mathrm{b}}$ & $210^{\mathrm{ab}}$ & $214^{\mathrm{a}}$ & $208^{\mathrm{ab}}$ & 7.32 & 0.008 & 0.02 & 0.009 \\
\hline Urine & $252^{\mathrm{a}}$ & $232^{\mathrm{ab}}$ & $184^{\mathrm{c}}$ & $212^{\mathrm{b}}$ & 11.3 & $<0.001$ & $<0.001$ & 0.002 \\
\hline Milk & $178^{\mathrm{a}}$ & $169^{\mathrm{b}}$ & $154^{\mathrm{c}}$ & $140^{\mathrm{d}}$ & 3.24 & $<0.001$ & $<0.001$ & 0.11 \\
\hline Urine N:milk N, g/g & $1.43^{\mathrm{a}}$ & $1.39^{\mathrm{ab}}$ & $1.20^{\mathrm{b}}$ & $1.55^{\mathrm{a}}$ & 0.08 & $<0.001$ & 0.50 & $<0.001$ \\
\hline \multicolumn{9}{|l|}{$\mathrm{N}$ partitioning, $\%$ of $\mathrm{N}$ intake } \\
\hline Feces & $31.6^{\mathrm{d}}$ & $34.3^{\mathrm{c}}$ & $38.8^{\mathrm{a}}$ & $37.2^{\mathrm{b}}$ & 0.40 & $<0.001$ & $<0.001$ & $<0.001$ \\
\hline Urine & $39.5^{\mathrm{a}}$ & $37.7^{\mathrm{a}}$ & $32.8^{\mathrm{b}}$ & $37.4^{\mathrm{a}}$ & 0.85 & $<0.001$ & $<0.001$ & $<0.001$ \\
\hline Milk & $29.0^{\mathrm{a}}$ & $28.0^{\mathrm{a}}$ & $28.4^{\mathrm{a}}$ & $25.4^{\mathrm{b}}$ & 0.95 & $<0.001$ & $<0.001$ & 0.06 \\
\hline Urine volume, L/d & $24.6^{\mathrm{ab}}$ & $25.0^{\mathrm{ab}}$ & $22.6^{\mathrm{b}}$ & $27.9^{\mathrm{a}}$ & 1.22 & 0.002 & 0.07 & 0.01 \\
\hline \multicolumn{9}{|l|}{ Urinary PD excretion, $\mathrm{mmol} / \mathrm{d}$} \\
\hline
\end{tabular}

${ }^{\mathrm{a}-\mathrm{d}} \mathrm{LSM}$ within the same row with different superscripts differ $(P<0.05)$.

${ }^{1}$ Experimental diets were composed of forage and concentrates $(75: 25)$, with targeted levels of red clover silage (RCS) in TMR of $15 \%$ (RCS 15$)$, $30 \%\left(\mathrm{RCS}_{30}\right), 45 \%\left(\mathrm{RCS}_{45}\right)$, and $60 \%\left(\mathrm{RCS}_{60}\right)$ on a $\mathrm{DM}$ basis.

${ }^{2} \mathrm{~L}=$ linear effect; $\mathrm{Q}=$ quadratic effect.

${ }^{3}$ Sum of allantoin and uric acid.

${ }^{4}$ Apparent total-tract digestibility of OM. 
Table 5. Milk yield and milk composition in lactating dairy cows fed the 4 experimental diets

\begin{tabular}{|c|c|c|c|c|c|c|c|c|}
\hline Item & \multicolumn{4}{|c|}{$\operatorname{Diet}^{1}$} & SEM & \multicolumn{3}{|c|}{$P$-value ${ }^{2}$} \\
\hline \multicolumn{9}{|l|}{ Milk yield, $\mathrm{kg} / \mathrm{d}$} \\
\hline $\mathrm{ECM}^{3}$ & $35.3^{\mathrm{a}}$ & $33.9^{\mathrm{b}}$ & $31.6^{\mathrm{c}}$ & $29.2^{\mathrm{d}}$ & 0.80 & $<0.001$ & $<0.001$ & 0.08 \\
\hline Fat & $1.43^{\mathrm{a}}$ & $1.36^{\mathrm{b}}$ & $1.29^{\mathrm{c}}$ & $1.19^{\mathrm{d}}$ & 0.04 & $<0.001$ & $<0.001$ & 0.10 \\
\hline Protein & $1.14^{\mathrm{a}}$ & $1.08^{\mathrm{b}}$ & $0.99^{\mathrm{c}}$ & $0.90^{\mathrm{d}}$ & 0.02 & $<0.001$ & $<0.001$ & 0.12 \\
\hline Fat, \% & $4.00^{\mathrm{ab}}$ & $3.94^{\mathrm{b}}$ & $4.04^{\mathrm{a}}$ & $3.97^{\mathrm{ab}}$ & 0.07 & 0.03 & 0.84 & 0.83 \\
\hline Protein, $\%$ & $3.20^{\mathrm{a}}$ & $3.12^{\mathrm{b}}$ & $3.09^{\mathrm{b}}$ & $3.01^{\mathrm{c}}$ & 0.06 & $<0.001$ & $<0.001$ & 0.80 \\
\hline Lactose, \% & 4.82 & 4.81 & 4.81 & 4.81 & 0.02 & 0.65 & 0.38 & 0.34 \\
\hline $\mathrm{SNF}, \%$ & $8.74^{\mathrm{a}}$ & $8.64^{\mathrm{b}}$ & $8.61^{\mathrm{b}}$ & $8.53^{\mathrm{c}}$ & 0.06 & $<0.001$ & $<0.001$ & 0.50 \\
\hline Urea, $\mathrm{mg} / \mathrm{kg}$ & $308^{\mathrm{a}}$ & $303^{\mathrm{a}}$ & $292^{\mathrm{b}}$ & $303^{\mathrm{a}}$ & 5.78 & $<0.001$ & 0.03 & 0.006 \\
\hline
\end{tabular}

${ }^{\mathrm{a}-\mathrm{d}}$ LSM within the same row with different superscripts differ $(P<0.05)$.

${ }^{1}$ Experimental diets were composed of forage and concentrates (75:25), with targeted levels of red clover silage (RCS) in TMR of $15 \%$ (RCS 15 ), $30 \%\left(\mathrm{RCS}_{30}\right), 45 \%\left(\mathrm{RCS}_{45}\right)$, and $60 \%\left(\mathrm{RCS}_{60}\right)$ on a DM basis.

${ }^{2} \mathrm{~L}=$ linear effect; $\mathrm{Q}=$ quadratic effect.

${ }^{3}$ Calculated as ECM $(\mathrm{kg})=$ milk yield $(\mathrm{kg}) \times[(0.38 \times$ milk fat $(\%)+0.21 \times$ milk protein $(\%)+1.05) / 3.28]$.

et al. (2016) and Broderick et al. (2001) observed marked increases in ATTD of NDF when cows were fed diets with increasing RCS-to-MS ratios and a RCSbased diet versus a diet containing RCS as a mixture with MS, respectively. In the present study, although the RCS and MS had similar NDF concentration and the overall diet NDF concentrations were similar among diets, the ATTD of NDF increased when the proportion of RCS plus wheat was increased. These results indicate that fiber digestibility was inherently greater for RCS than MS, possibly due to higher rate of fiber fermentation in the rumen (Dewhurst, 2013), which might result from differences in anatomical characteristics or stage of maturity at harvest between red clover and maize plants (Wilson and Kennedy, 1996; Buxton and Redfearn, 1997). In line with this, Dewhurst et al. (2010) suggested that NDF of MS was less digestible than of RCS, and Margan et al. (1994) reported lower NDF digestibility of MS than red clover hay in sheep. Moreover, Dewhurst et al. (2003a) suggested that digesta kinetics were influenced by the persistent mat in the rumen when feeding RCS, which increased retention time in the rumen and fiber digestibility. It appears unlikely that the increase in ATTD of NDF and ADF found in the present study resulted from a more favorable rumen environment (i.e., $\mathrm{pH}$ ) for activity of cellulolytic bacteria due to a lower intake of rapidly fermentable carbohydrates in diets with higher proportions of RCS. The NDF concentrations of all diets were considerably higher than the minimum recommendation of NRC (2001); thus, sufficient ruminal buffering from chewing activity and salivation due to adequate structural supply was expected for all diets. Moreover, even the highest dietary proportion of MS (i.e., $\mathrm{RCS}_{15}$ ) did not induce milk fat depression, indicating the maintenance of a physiological rumen $\mathrm{pH}$. Although the ATTD of NDF markedly increased as the proportion of RCS plus wheat was increased in the diet, ATTD of OM remained unaffected. Hence, the reduced ATTD of N and the lower dietary concentration of starch appeared to compensate for the greater ATTD of fiber fractions when increasing the proportion of RCS plus wheat. A linear decline in ATTD of N, as observed in the present study, was also reported by Moorby et al. (2016) when dairy cows were fed diets with increasing RCS-to-MS ratios. In contrast, other studies found no differences in ATTD of $\mathrm{N}$ when increasing the RCS-to-MS ratio (Dewhurst et al., 2010) or when feeding RCS as the sole forage source versus a RCS-MS mixture (Broderick et al., 2001; Cheng et al., 2011). However, the decline in ATTD of $\mathrm{N}$ in our study may suggest that the intestinal digestibility of dietary $\mathrm{CP}$ decreased when the proportion of RCS plus wheat was increased, probably due to an incomplete dissociation of the protein-bound phenol complexes caused by the activity of PPO in red clover (Huhtanen et al., 2014).

Reduced DMI with increasing levels of RCS plus wheat in spite of ATTD of DM and OM remaining unchanged seems to be contradictory. Legume silages generally lead to higher intakes than grass silages of comparable digestibility (Dewhurst, 2013). In line with this, Moorby et al. (2016) fed dairy cows RCS-to-MS ratios (on DM basis) of 10:90, 50:50, and 90:10 in the forage portion and observed the greatest DMI at the 50:50 ratio. However, a decline in DMI, as found in the present study, was also observed by Broderick et al. 
(2001) and Hoffman and Bauman (2003) when dairy cows were fed RCS-based diets. Similarly, Kuoppala et al. (2009) found low DMI of highly digestible RCS. Conversely, Dewhurst et al. (2010) found no effect of RCS-to-MS ratios (25:75 and 40:60 on a DM basis) on DMI. Greater chopping length of RCS compared with MS ( 15 vs. 0.6 to $1 \mathrm{~cm}$ ) in our study might have contributed, at least in part, to the reduced DMI when RCS plus wheat was increased in the diet. However, in the study of Broderick et al. (2001) and Hoffman and Bauman (2003), DMI was also negatively affected by increasing proportion of RCS, although RCS was chopped to a theoretical length of 2.9 and $1 \mathrm{~cm}$, respectively. The reason for the unexpectedly lower DMI with increasing levels of RCS cannot be explained with certainty using the existing data in the present study and needs further investigation. However, reduced DMI could be attributed to metabolic factors regulating feed DMI (Kuoppala et al., 2009); factors associated with high rates of absorption of ammonia-N from the rumen (Choung et al., 1990) probably caused by high content of NPN of RCS; to other aspects of nutrient composition; or was influenced by formation of persistent mat in the rumen that trapped feed particles, increased retention time (Dewhurst et al., 2003a), and limited feed intake.

\section{Nitrogen Excretion and Partitioning}

Considering that the experimental diets were isonitrogenous, differences in $\mathrm{N}$ intake were mainly affected by DMI. Because overall $\mathrm{N}$ intake largely affects the amount of $\mathrm{N}$ excreted via manure in dairy cows (Dijkstra et al., 2013), $\mathrm{N}$ excretions (feces, urine, and milk) as a proportion of $\mathrm{N}$ intake (\%) are specifically discussed here. Fecal $\mathrm{N}$ excretion increased as the proportion of RCS plus wheat increased in the diet, which is consistent with other studies when feeding RCS-based diets (Halmemies-Beauchet-Filleau et al., 2014; Moorby et al., 2016). The increased fecal $\mathrm{N}$ excretion in the present study was partly due to reduction in ATTD of N, which could lead to less digestible protein for absorption by the animal (Moorby et al., 2016). At the same time, urinary $\mathrm{N}$ excretion was reduced with increasing levels of RCS plus wheat. To the contrary, Moorby et al. (2016) reported a linear increase in the partitioning of dietary $\mathrm{N}$ into urine with increasing RCS-to-MS ratio, whereas Dewhurst et al. (2010) found no difference in urinary $\mathrm{N}$ excretion when feeding dairy cows different RCS-MS mixtures. However, the effects reported by Moorby et al. (2016) were probably confounded by greater dietary $\mathrm{CP}$ concentrations with increasing RCSto-MS ratio in the diets. The lower urinary $\mathrm{N}$ excretion with feeding $\mathrm{RCS}_{45}$ compared with $\mathrm{RCS}_{15}$ and $\mathrm{RCS}_{30}$ was somehow surprising. Increasing the proportion of RCS plus wheat resulted in a decrease in the concentration of rapidly fermentable carbohydrates (starch and sugar) and a simultaneous increase in the concentration of rapidly fermentable N (NPN), suggesting an increasing asynchrony between supply of fermentable energy and $\mathrm{N}$ for the microbes in the rumen. Due to this asynchrony, CP that was degraded in the rumen could not be incorporated into MCP and would be absorbed from the rumen, converted to urea in the liver, and excreted in urine (Moorby et al., 2016). It has to be noted that possible changes in body $\mathrm{N}$ were not included in the $\mathrm{N}$ balance calculation, which might have led to inaccuracies in estimates of urinary $\mathrm{N}$ excretion. However, first, using BW data of cows and assuming body tissue contains $13.8 \%$ protein (GfE, 2001), changes in body $\mathrm{N}$ were only small, ranging from $0.1\left(\mathrm{RCS}_{60}\right)$ to $1.6 \%$ of $\mathrm{N}$ intake $\left(\mathrm{RCS}_{15}\right)$. Second, the effect of diets on urinary $\mathrm{N}$ excretion was similarly reflected in milk urea concentration, being lowest $\left(292 \mathrm{mg} / \mathrm{kg}\right.$ of milk) with $\mathrm{RCS}_{45}$.

The proportion of dietary $\mathrm{N}$ that was secreted in milk declined linearly when the proportion of RCS plus wheat increased in the diet and was the lowest (25.4\%) when feeding $\mathrm{RCS}_{60}$, which was accompanied by a simultaneous increase in urinary $\mathrm{N}$ excretion compared with $\mathrm{RCS}_{45}$. In general, reduced $\mathrm{N}$ efficiency suggested that higher silage NPN $\left(\mathrm{RCS}_{60}\right)$ reduced $\mathrm{N}$ utilization. Similarly, several studies observed that the N efficiency decreased when cows were fed diets with increasing RCS-to-MS ratios (Dewhurst et al., 2010; Moorby et al., 2016) or a RCS-based diet versus a diet containing RCS as a mixture with MS (Broderick et al., 2001). The decline in urine $\mathrm{N}$ excretion per unit of milk produced ( $\mathrm{g} / \mathrm{kg}$ of milk or $\mathrm{g} / \mathrm{g}$ of milk $\mathrm{N}$; Table 4 ), and the lowest urine $\mathrm{N}$ (\% of $\mathrm{N}$ intake) when feeding $\mathrm{RCS}_{45}$ compared with the other diets can be considered positive from an environmental point of view, because urinary $\mathrm{N}$ is more susceptible to volatile $\mathrm{N}$ losses than fecal N (Dijkstra et al., 2013).

\section{Urinary Excretion of PD}

Urinary PD excretion decreased linearly when RCS plus wheat increased in the diet. In contrast, Moorby et al. (2016) observed a tendency of a linear increase in urinary PD excretion with increasing RCS-to-MS ratio (on a DM basis) from 10:90 to 90:10. Dewhurst et al. (2010) and Cheng et al. (2011) found no differences in urinary PD excretion when comparing different RCSMS mixtures or when feeding RCS as the sole forage source versus an RCS-MS mixture. Urinary PD excretion is commonly used as indicator for rumen MCP synthesis (Henke et al., 2017); hence, the decrease in urinary PD excretion in our study suggests that RCS 
plus wheat reduced the MCP flow to the duodenum. The MCP synthesis depends largely on the availability of carbohydrates and $\mathrm{N}$ in the rumen (Shabi et al., 1998) and is primarily limited by rumen available energy (Henke et al., 2017). Moreover, the synchronicity of ruminal degradation of dietary $\mathrm{CP}$ and energy availability plays an important role in optimizing ruminal MCP synthesis (Hoover and Stokes, 1991; Schingoethe, 1996; Dewhurst et al., 2000). Indeed, in the present study, increasing the proportion of RCS plus wheat in the diet resulted in a simultaneous decrease of rapidly fermentable carbohydrates and increase of rapidly fermentable $\mathrm{N}$, which suggests that the reduction of MCP flow to the duodenum might have been influenced by increasing asynchrony between supply of energy and $\mathrm{N}$ in the rumen, which seemed to induce negative associative effects, as postulated by Westreicher-Kristen et al. (2017). Additionally, the reduced content of dietary sugar and starch may have reduced the availability of rapidly fermentable energy for ruminal microbes and, in turn, reduced MCP synthesis. However, urinary PD excretion related to apparently digested $\mathrm{OM}$ was unaffected, suggesting that the efficiency of MCP synthesis was similar across diets. Hence, the decrease in urinary $\mathrm{PD}$ excretion mainly resulted from the reduction in OM intake when increasing the proportion of RCS plus wheat in the diet.

\section{Milk Yield and Milk Composition}

Milk yield was markedly reduced as RCS plus wheat increased in the diet. Other studies (Broderick et al., 2001; Hoffman and Bauman, 2003) also observed lower milk yields when cows were fed RCS-based diets versus diets containing RCS-MS mixtures. Moorby et al. (2016) found a nonlinear effect on milk yield when feeding dairy cows diets with increasing RCS-to-MS ratios, with maximal milk yield at the 50:50 ratio. As also observed by Moorby et al. (2016), we noted depression in milk yield in the present study with increasing proportion of RCS plus wheat, related to a reduction in DMI. Additionally, content of rapidly fermentable carbohydrates (Schingoethe, 1996) and intake and energy content in the diet are factors that influence the milk yield. Indeed, energy concentration in the diet decreased from $\mathrm{RCS}_{15}$ to $\mathrm{RCS}_{60}$ caused by a lower energy concentration of RCS compared with MS and due to a reduced content of rapidly fermentable carbohydrates when increasing the proportion of RCS and wheat in the diet. Moreover, the combination of the reduced content of rapidly fermentable carbohydrates and the reduced DMI dramatically reduced intake of sugar and starch by 55 and $35 \%$, respectively, when increasing the proportion of RCS and wheat from $\mathrm{RCS}_{15}$ to $\mathrm{RCS}_{60}$.
Milk fat concentration was increased when cows were fed $\mathrm{RCS}_{45}$ compared with those fed $\mathrm{RCS}_{30}$. However, neither a linear nor quadratic effect on milk fat concentration could be noted. Several studies reported that milk fat concentration was unaffected by the RCS-toMS ratio (Dewhurst et al., 2010; Moorby et al., 2016) or when feeding RCS as the sole forage source versus an RCS-MS mixture (Broderick et al., 2001; Hoffman and Bauman, 2003; Cheng et al., 2011).

Milk protein concentration decreased linearly as RCS plus wheat increased in the diet. Similar to our results, Moorby et al. (2016) found a linear decline in milk protein concentration, from 3.09 to $2.99 \%$, when MS was partially replaced by RCS. Other studies, conversely, found no effect on milk protein concentration when comparing RCS-MS mixtures (Dewhurst et al., 2010) or when feeding RCS as the sole forage source versus an RCS-MS mixture (Hoffman and Bauman, 2003; Cheng et al., 2011). Decreased milk protein concentration might be caused by a decreased duodenal MCP flow, as indicated by the linear reduction in urinary PD excretion and, in turn, reduced the amount of protein available for milk protein synthesis. Similarly, when testing samples of the experimental diets used in this study with an in vitro procedure, Westreicher-Kristen et al. (2017) observed a linear decrease in the utilizable $\mathrm{CP}$ at the duodenum (sum of MCP and RUP) with increasing level of RCS plus wheat. However, it must be considered that dietary RUP supplies a substantial amount of AA for milk protein synthesis (WestreicherKristen et al., 2014), and, therefore, differences in RUP supply between diets could also explain possible effects on milk protein concentration. Hence, in the current study, it was not possible to differentiate whether the reduced milk protein concentration was caused by reduced MCP synthesis alone (based on PD excretion) or in combination with reduced RUP flow to the intestine. Additionally, because the intestinal digestibility of the RUP fraction is a prerequisite for calculating the AA supply to the cow (Westreicher-Kristen et al., 2013), this should be considered as a possible influence on the supply of available protein for milk protein synthesis. Therefore, this possible RUP effect remains unsolved and needs further research.

The fact that ATTD of $\mathrm{N}$ was reduced suggests that probably less dietary $\mathrm{CP}$ was digested in the small intestine when RCS plus wheat was increased, thereby lowering the supply of dietary AA available to the cow. In the literature, a possible role of PPO in protecting particularly sulfur-containing AA from ruminal degradation, but also from intestinal digestibility, is discussed (Lee, 2014). Replacing grass silage with RCS progressively reduced ruminal degradation of Met and Cys (Halmemies-Beauchet-Filleau et al., 2014), but a 
reduced transfer of Met from the small intestine into plasma was also shown (Vanhatalo et al., 2009). In line with this, Lee et al. (2009) observed lower ATTD of Met when feeding red clover compared with grass. Because Met was identified as one of the most limiting AA for growth and milk protein production in dairy cattle (NRC, 2001), Vanhatalo et al. (2009) suggested that reduced availability of Met for absorption might also be a reason for reduced milk protein concentration on RCS-based diets.

\section{CONCLUSIONS}

This study shows that increasing the proportion of RCS plus wheat at the expense of MS plus SBM in diets for lactating dairy cows reduces DMI, ME intake, MCP flow to the duodenum, and milk yield. Therefore, caution should be taken before introducing high levels of RCS plus wheat when mixed with MS in diets of high-yielding dairy cows. However, N efficiency was only considerably reduced when the highest proportions of RCS plus wheat were fed. Under conditions of the present study, RCS in combination with MS can be included up to $30 \%$ of the dairy cow diet (DM basis) without a reduction in lactation performance; therefore, RCS has the potential to partially replace SBM. In addition, reducing the proportions of feed protein supplements (e.g., SBM or rapeseed meal) and the related costs, as well as the positive effects of red clover on soil fertility and the environment, have to be considered before a final conclusion can be made about the potential of RCS for feeding dairy cows. Whether reduced RUP flow at the duodenum or reduced digestibility of RUP or AA also influenced the reduction of milk protein concentration with increasing levels of RCS remains unsolved in this study; therefore, further research addressing this aspect is recommended.

\section{ACKNOWLEDGMENTS}

This study was funded by the Federal Ministry of Education and Research, in Berlin, Germany, within the research project "Food Chain Plus" (project number 0315538A; 2010-2015). Skillful technical assistance and care of the experimental animals by the personnel of the experimental farm Schädtbek of the Max Rubner-Institute is highly appreciated. Furthermore, many thanks to Ann-Kristin Licht and Gwendolyn Keinarth of the Christian-Albrechts-Universität zu Kiel for the help during the feeding experiment. Additionally, the authors are very grateful for the valuable laboratory work of Annette Hollmann and Monika Paschke-Beese of the Institute of Animal Nutrition and Physiology of the Christian-Albrechts-Universität zu Kiel. The au- thors acknowledge Mario Hasler of the Lehrfach Variationsstatistik of the Christian-Albrechts-Universität zu Kiel for statistical advice.

\section{REFERENCES}

Bittner, S. 2006. When quinones meet amino acids: Chemical, physical and biological consequences. Amino Acids 30:205-224.

Brandt, M., A. Schuldt, P. Mannerkorpi, and T. Vearasilp. 1987. Zur enzymatischen Stärkebestimmung im Darminhalt und Kot von Kühen mit hitzestabiler Amylase. Arch. Anim. Nutr. 37:455.

Broderick, G. A. 1995. Desirable characteristics of forage legumes for improving protein utilization in ruminants. J. Anim. Sci. 73:27602773.

Broderick, G. A., R. P. Walgenbach, and S. Maignan. 2001. Production of lactating dairy cows fed alfalfa or red clover silage at equal dry matter or crude protein contents in the diet. J. Dairy Sci. 84:1728-1737.

Buxton, D. R., and D. D. Redfearn. 1997. Plant limitations to fiber digestion and utilization. J. Nutr. 127:814S-818S.

Castro-Montoya, J., A. Henke, J. Molkentin, K. Knappstein, A. Susenbeth, and U. Dickhoefer. 2016. Relationship between milk odd and branched-chain fatty acids and urinary purine derivatives in dairy cows supplemented with quebracho tannins - A study to test milk fatty acids as predictors of rumen microbial protein synthesis. Anim. Feed Sci. Technol. 214:22-33.

Cheng, L., E. J. Kim, R. J. Merry, and R. J. Dewhurst. 2011. Nitrogen partitioning and isotopic fractionation in dairy cows consuming diets based on a range of contrasting forages. J. Dairy Sci. 94:2031-2041.

Choung, J. J., D. G. Chamberlain, P. C. Thomas, and I. Bradbury. 1990. The effect of intraruminal infusions of urea on the voluntary intake and milk production of cows receiving grass silage diets. J. Dairy Res. 57:455-464.

Dewhurst, R. J. 2013. Milk production from silage: Comparison of grass, legume and maize silages and their mixtures. Agric. Food Sci. 22:57-69.

Dewhurst, R. J., D. R. Davies, and R. J. Merry. 2000. Microbial protein supply from the rumen. Anim. Feed Sci. Technol. 85:1-21.

Dewhurst, R. J., L. J. Davies, and E. J. Kim. 2010. Effects of mixtures of red clover and maize silages on the partitioning of dietary nitrogen between milk and urine by dairy cows. Animal 4:732-738.

Dewhurst, R. J., R. T. Evans, N. D. Scollan, J. M. Moorby, R. J. Merry, and R. J. Wilkins. 2003a. Comparison of grass and legume silages for milk production. 2. In vivo and in sacco evaluations of rumen function. J. Dairy Sci. 86:2612-2621.

Dewhurst, R. J., W. J. Fisher, J. K. S. Tweed, and R. J. Wilkins. 2003b. Comparison of grass and legume silages for milk production. 1. Production responses with different levels of concentrate. J. Dairy Sci. 86:2598-2611.

Dijkstra, J., O. Oenema, J. W. van Groenigen, J. W. Spek, A. M. van Vuuren, and A. Bannink. 2013. Diet effects on urine composition of cattle and $\mathrm{N}_{2} \mathrm{O}$ emissions. Animal 7:292-302.

Federal Republic of Germany. 2014. Tierschutzgesetz. https://www .gesetze-im-internet.de/tierschg/BJNR012770972.html.

GfE (Gesellschaft für Ernährungsphysiologie). 2001. Empfehlungen zur Energie- und Nährstoffversorgung der Milchkühe und Aufzuchtrinder. DLG-Verlag, Frankfurt am Main, Germany.

Glindemann, T., B. M. Tas, C. Wang, S. Alvers, and A. Susenbeth. 2009. Evaluation of titanium dioxide as an inert marker for estimating faecal excretion in grazing sheep. Anim. Feed Sci. Technol. 152:186-197.

Halmemies-Beauchet-Filleau, A., A. Vanhatalo, V. Toivonen, T. Heikkilä, M. R. F. Lee, and K. J. Shingfield. 2014. Effect of replacing grass silage with red clover silage on nutrient digestion, nitrogen metabolism, and milk fat composition in lactating cows fed diets containing a 60:40 forage-to-concentrate ratio. J. Dairy Sci. 97:3761-3776.

Henke, A., U. Dickhoefer, E. Westreicher-Kristen, K. Knappstein, J. Molkentin, M. Hasler, and A. Susenbeth. 2017. Effects of quebra- 
cho tannin extract on feed intake, digestibility, excretion of urinary purine derivatives and milk production in lactating dairy cows. Arch. Anim. Nutr. 71:37-53.

Hoffman, P. C., and L. M. Bauman. 2003. Strategies to improve milk yield of lactating dairy cows fed red clover silage. Prof. Anim. Sci. 19:178-187.

Hoover, W. H., and S. R. Stokes. 1991. Balancing carbohydrates and protein for optimum rumen microbial yield. J. Dairy Sci. 74:36303644.

Huhtanen, P., A. Bayat, S. J. Krizsan, and A. Vanhatalo. 2014. Compartmental flux and in situ methods underestimate total feed nitrogen as judged by the omasal sampling method due to ignoring soluble feed nitrogen flow. Br. J. Nutr. 111:535-546.

Hymes-Fecht, U. C., G. A. Broderick, R. E. Muck, and J. H. Grabber. 2013. Replacing alfalfa or red clover silage with birdsfoot trefoil silage in total mixed rations increases production of lactating dairy cows. J. Dairy Sci. 96:460-469.

Jones, B. A., R. E. Muck, and R. D. Hatfield. 1995. Red clover extracts inhibit legume proteolysis. J. Sci. Food Agric. 67:329-333.

Kuoppala, K., S. Ahrenjärvi, M. Rinne, and A. Vanhatalo. 2009. Effects of feeding grass or red clover silage cut at two maturity stages in dairy cows. 2. Dry matter intake and cell wall digestion kinetics. J. Dairy Sci. 92:5634-5644.

Lee, M. R. F. 2014. Forage polyphenol oxidase and ruminant livestock nutrition. Front. Plant Sci. 5:694.

Lee, M. R. F., V. J. Theobald, J. K. S. Tweed, A. L. Winters, and N. D. Scollan. 2009. Effect of feeding fresh or conditioned red clover on milk fatty acids and nitrogen utilization in lactating dairy cows. J. Dairy Sci. 92:1136-1147.

Licitra, G., T. M. Hernandez, and P. J. Van Soest. 1996. Standardization of procedures for nitrogen fractionation of ruminant feeds. Anim. Feed Sci. Technol. 57:347-358.

Margan, D. E., J. B. Moran, and F. B. Spence. 1994. Energy and protein value of combinations of maize silage and red clover hay for ruminants, using adult sheep as a model. Aust. J. Exp. Agric. 34:319-329.

Menke, K. H., and H. Steingass. 1988. Estimation of the energetic feed value obtained from chemical analysis and in vitro gas production using rumen fluid. Anim. Res. Dev. 28:7-55.

Merry, R. J., M. R. F. Lee, D. R. Davies, R. J. Dewhurst, J. M. Moorby, N. D. Scollan, and M. K. Theodorou. 2006. Effects of high-sugar ryegrass silage and mixtures with red clover silage on ruminant digestion. 1. In vitro and in vivo studies of nitrogen utilization. J. Anim. Sci. 84:3049-3060.

Moorby, J. M., N. M. Ellis, and D. R. Davies. 2016. Assessment of dietary ratios of red clover and corn silages on milk production and milk quality in dairy cows. J. Dairy Sci. 99:7982-7992.
Moorby, J. M., M. R. F. Lee, D. R. Davies, E. J. Kim, G. R. Nute, N. M. Ellis, and N. D. Scollan. 2009. Assessment of dietary ratios of red clover and grass silages on milk production and milk quality in dairy cows. J. Dairy Sci. 92:1148-1160.

NRC. 2001. Nutrient Requirements of Dairy Cattle. 7th rev. ed. Natl. Acad. Press, Washington, DC.

Schingoethe, D. J. 1996. Dietary influence on protein level in milk and milk yield in dairy cows. Anim. Feed Sci. Technol. 60:181-190.

Shabi, Z., A. Arieli, I. Bruckental, Y. Aharoni, S. Zamwel, A. Bor, and H. Tagari. 1998. Effect of synchronization of the degradation of dietary crude protein and organic matter and feeding frequency on ruminal fermentation and flow of digesta in the abomasum of dairy cows. J. Dairy Sci. 81:1991-2000.

Sullivan, M. L., and R. D. Hatfield. 2006. Polyphenol oxidase and odiphenols inhibit postharvest proteolysis in red clover and alfalfa. Crop Sci. 46:662-670.

Vanhatalo, A., K. Kuoppala, S. Ahvenjärvi, and M. Rinne. 2009. Effects of feeding grass or red clover silage cut at two maturity stages in dairy cows. 1. Nitrogen metabolism and supply of amino acids. J. Dairy Sci. 92:5620-5633.

VDLUFA (Verband Deutscher Landwirtschaftlicher Untersuchungsund Forschungsanstalten). 2007. Handbuch der Landwirtschaftlichen Versuchs- und Untersuchungsmethodik (VDLUFA Methodenhandbuch), Bd. III. Die chemische Untersuchung von Futtermitteln. VDLUFA-Verlag, Darmstadt, Germany.

Verbic, J., X. B. Chen, N. A. Macleod, and E. R. Ørskov. 1990. Excretion of purine derivatives by ruminants - effect of microbial nucleic acid infusion on purine derivative excretion by steers. J. Agric. Sci. 114:243-248.

Westreicher-Kristen, E., R. Blank, F. Schulz, and A. Susenbeth. 2017. Replacing maize silage with red clover silage in total mixed rations for dairy cows: In vitro ruminal fermentation characteristics and associative effects. Anim. Feed Sci. Technol. 227:131-141.

Westreicher-Kristen, E., R. Kaiser, H. Steingass, and M. Rodehutscord 2014. Effect of feeding dried distillers' grains with solubles on milk yield and milk composition of cows in mid-lactation and digestibility in sheep. J. Anim. Physiol. Anim. Nutr. (Berl.) 98:347-356.

Westreicher-Kristen, E., H. Steingass, and M. Rodehutscord. 2013. In situ degradation of amino acids and in vitro protein digestibility of undegraded $\mathrm{CP}$ of dried distillers' grains with solubles from European ethanol plants. Animal 7:1901-1909.

Wilson, J. R., and P. M. Kennedy. 1996. Plant and animal constraints to voluntary feed intake associated with fibre characteristics and particle breakdown and passage in ruminants. Aust. J. Agric. Res. $47: 199-225$. 